\title{
RESTRICTIONS ON DATIVE CLITICIZATION IN FRENCH CAUSATIVES*
}

\author{
JOHAN ROORYCK
}

\begin{abstract}
Causative constructions in French display restrictions as to the cliticization of lexical datives onto the causatıve In altogether difterent frameworks, Fauconnier (1983), Burzıo (1986) and Goodall (1987) have related this restriction to the ergative-mergative distinction However, the inability to formally define ergative verbs in French, as well as further restrictions on the cliticization of datives in causative constructions show that this hypothesis fals to account for the data observed A thematic condition on dative cliticization in causatives adequately describes the iestrictions noted
\end{abstract}

\section{INTRODUCTION}

Recent work on causative 'restructuring'" constructions in French (Fauconnier 1983; Tasmowski 1984; Burzio 1986) draws the attention to the fact that syntactically similar verbs differ with respect to the cliticization of their animate indirect object or dative complement when inserted into the causative construction. This difference appears most strikingly when verbs corresponding to the $N P I V P \grave{a} N P 2 \leftrightarrow N P 1$ lui2 $V P$ format are constructed with a causative.

(1) a. J'ai fait parvenir/arriver cette lettre à son amie.

'I made that letter arrive to her friend.'

b. Je lui ai fait parvenir/arriver cette lettre. 'I (to her) made arrive that letter.

(2) a. J'ai fait nuire/obéir/ressembler Oscar à ce général.

'I made Oscar harm/obey/resemble that general.'

b. *Je lui ai fait nuire/obéir/ressembler Oscar.

'I made him harm/obey/resemble that general.'

These restrictions also apply to certain verbs selecting both a direct and indirect object (téléphoner, répondre) or two indirect objects (parler) when only the dative is expressed. 
a. J'ai fait/vu téléphoner/parler/répondre Oscar à son frère. 'I made/saw Oscar call/talk to his brother.'

b. *Je lui ai fait/vu téléphoner/parler/répondre Oscar. 'I made/ saw him call/talk to his brother.'

a. J'ai fait/vu donner/conseiller/interdire ce livre à Luc par Max. 'I made/saw give/recommend/refuse that book to Luc by Max.'

b. Je lui ai fait/vu donner/conseiller/interdire ce livre par Max. 'I made/saw him give/recommend/refuse that book by Max.'

In order to explain this observation, both relational grammar (Fauconnier 1983) and Chomskyan generative grammar (Burzio 1986) distinguish two classes among the verbs selecting both a subject and an indirect object. They claim that the superficial subject of 'inaccusative verbs' ( $R G$ ) or 'ergative' verbs like parvenir, arriver (GG) actually is a direct object at the right side of the verb in deep structure. As such, these verbs cannot constitute an $\mathrm{S}$, but necessarily form a VP. Hence, the anaphor of the dative selected by ergative verbs escapes the Opacity condition when attached to the causative. Both Burzio (1986) and Fauconnier (1983) choose to solve this problem by a double subcategorization of the causative for $\mathrm{S}$ and $\mathrm{VP}$ respectively. The possibility of sentences like (4b) is explained by the passive interpretation of the embedded infinitive, but this problem will not concern us here. ${ }^{2}$

Goodall (1987:128-129) does not accept this double subcategorization scheme for causatives. His analysis mainly rests on a combination of the ergative hypothesis and Case theory. Goodall (1987) assumes that the causative cannot assign accusative case to Oscar in (2b) and (3b) because of the intervening trace of lui. Since Oscar is not adjacent to the complex verb constituted by the causative and the infinitive, Case cannot be assigned and (3b) is ruled out by the Case filter. Goodall (1987) then predicts that whenever the embedded subject does not need Case, the PP complement of the infinitive can freely cliticize on the causative. For Goodall (1987), this is the case in (4b) where the embedded verb need not assign Case to the subject position, since the verb is interpreted as a passive. This situation also occurs in (1b), since inaccusative/ergative verbs do not assign a thematic role and hence no Case to their subject position.

In the remainder of this article, I will critically examine both the analysis based on Case theory and the approaches that only makes use of the ergative-inergative distinction. Moreover, I will try to show that a thematic condition on the cliticization of datives onto the causative construction is sufficient to account for the restrictions concerning both 'ergative' verbs (1) (2) and ditransitive verbs (3) (4). 


\section{PROBLEMS FOR CASE THEORY}

Goodall's (1987) account of the restrictions on Dative cliticization on the causative does not seem adequate for both theoretical and empirical reasons. A first problem involves the explanation of (3a). The acceptability of this sentence is explained as a result of the extraposition of the dative complement in the following sentence.

*J'ai fait/vu téléphoner/écrire/répondre à son frère Oscar. 'I made call/write/answer to his brother Oscar.'

Goodall (1987:181 n9) assumes that this rule does not involve movement. Consequently, no trace is present to block Case assignment. However, if no movement is involved, extraposition must be viewed as a stylistic rule operating in Phonological Form. This rule should then be ordered before the application of the Case filter, otherwise the rule would have nothing to operate upon: (5) would be excluded by the Case filter because of the intervening $\mathrm{PP}$ complement. This ordering of filters and stylistic rules is certainly not a desirable result.

A further problem we want to point out in Goodall's (1987) analysis concerns the exclusion of (5) by virtue of the Case filter. How are acceptable sentences like the following to be explained?

(6) L'infirmière a fait téléphoner à leurs parents tous les enfants qui avaient pleuré pendant la nuit.

'The nurse made call to their parents all the children who cried during the night.'

Apparently, sentences like (5) are perfectly acceptable when the subject is heavier. This pragmatic restriction of 'NP Heaviness' is a well-known for the stylistic postposition of embedded subjects in French (see Bailard 1981 for discussion).

(7) a. Il dit qu'ont été acceptés tous les candidats qui s'étaient présentés ce matin.

'He says that have been accepted all the candidates who came this morning.'

b. *Il dit qu'a ẻté acceptée Violaine.

'He says that has been accepted Violaine.

Consequently, it seems much more adequate to analyze (5) and (6) along the lines of (7) as sentences where the infinitival subject has been postposed. In this way, the need for a theoretically awkward Dative extraposition rule disappears. 
The analysis under discussion also makes for some empirically inadequate predictions. Since the trace of the dative blocks Case assignment in (2b) and (3b), sentences where the dative is subject to Wh-movement should be equally unacceptable. However, this is not the case.

(8) a. Voilà l'homme à qui j'ai fait/vu téléphoner/répondre les enfants.

'This is the man to whom I made/saw call/answer the children.'

b. Voilà la femme à laquelle le sculpteur a fait ressembler sa statue. 'This is the woman to whom the sculptor made resemble his statue.'

The restrictions noted in (1)-(3) only seem to involve cliticization, contrary to what is predicted by Goodall (1987). Moreover, Goodall's (1987) analysis predicts the unacceptability of sentences where PP complements other than datives are cliticized. Verbs like ressembler, échapper, survivre or répondre select an indirect object of the $+/$ - Animate type that can be cliticized as resp. lui or $y$.

(9) Cunégonde y/lui ressemble/survit/échappe/répond.

'Cunégonde (to it/him/her) resembles/survives/escapes/answers.'

When inserted in the causative construction, the dative cannot be cliticized on the causative, but the $y$ clitic can. Compare (1)-(3) and the following:

(10) a. Le sculpteur y a fait ressembler sa statue (a l'idée du bonheur). 'The sculptor (to it) made his statue resemble (to the idea of happiness).'

b. Mon grand-père y a fait survivre ses trois enfants (à la seconde guerre mondiale).

'My grandfather (to it) made live through his thr ee children (the second World War).'

c. J'y ai fait/entendu répondre mon frère avec grand aplomb (à cette question).

'I (to it) made/saw answer my brother undisturbedly (to that question).'

Now Goodall's (1987) analysis predicted that so-called inergative verbs cannot cliticize PP complements onto the causative. The trace of the PP complement should make Case assignment impossible in both (2)-(3b) and (6). Nevertheless, the sentences in (6) are acceptable. For this problem, the only way to save Goodall's (1987) analysis would be to distinguish homonyms for the abovementioned verbs: an 'ergative' verb with $y$ and an inergative verb 
with luı This rather unplausible solution brings us to another problem for all analyses outlined in the preceding paragraph the definition of ergative verbs

\section{PROBLEMS FOR THE ERGATIVE HYPOTHESIS}

All solutions sketched have two serious drawbacks First, the formal definı tion of ergative verbs in French does not seem to apply to all verbs allowing for their dative to be cliticized on the causative A second and more serious problem for the ergative hypothesis lies in the observation that so-called inergative verbs are not the only verbs for which datıve clitıcization onto the causative is excluded

As far as the formal definition of ergative verbs is concerned, Tasmowsk 1 (1984) has pointed out that it is very difficult to define ergative verbs in French, since the formal tests that have been proposed cannot always be applied rigorously This problem is worth being analyzed in some detall A quick glance at Gross's (1975) lists 5 and 7 learns tnat 35 verbs correspond to the format NPI VP a NP2 $\leftrightarrow N P I$ lul $2 V P$ Of these verbs, 1 belongs to a literary register (agreer), and 16 do not enter the causative scheme because they are stative and have a nonagentive subject, ${ }^{3} 8$ verbs enter the scheme NPI lul Vcaus Vinf NP2, and thus would be ergative revenir, profiter, incomber, echoir, beneficler, apparaitre, arriver, parvenir 10 verbs do not enter the scheme, but their indirect object can be realized lexically at the right of the causative construction ceder, echapper, faire obstacle, mentir, obetr, resister, sourire, surceder, survivre, ressembler Now, considering that most examples adduced in the literature on ergativity in French concern movement verbs, it $\varsigma$ ems hard to prove that profiter, $i n$ comber, echoir, beneficier are ergat1 e, while echapper, clearly a movement verb, is not Ruwet (1988) argues that the property of taking être as an auxiliary in the perfect tenses is a sufficient condition for ergativity According to this definition, echapper rould be inergative, since its perfect tenses displays avoir in the construction with a dative However, the ergative status of beneficier, incomber, and profiter cannot be defined in this way, since they also have avour in the past tense Nevertheless, these verbs satisfy some other tests for ergativity cied by Tasmowsk1 (1985) beneficler, profiter can display a partitive en originatıng in the 'subject' of the ergatıve verb, and they do not have an impersonal passive

(11) a Une partie en a beneficie/profite aux rebelles

'Part of it profited to the rebels'

b * Il a ete beneficie/profite aux rebelles

'There was profited to the rebels' 
However, Tasmowsk1 (1985 335-336) points out that these tests are inoperative for a number of reasons that will not concern us here Finally, Ruwet (1988) notes that ergatives take the repetitive suffix re- Echorr, beneficler, profiter do not share this morphological characteristic Moreover, it can be doubted whether this test applies to all ergatives, since the movement verb arriver, a candidate for ergatıvity (cfr supra) does not have it either These problems for a clear definition of ergative verbs in French show that the ergative-inergative distinction in French is too unprecise a tool to handle restrictions on causatives with Moreover, it is quite unsatisfactory to note that a clear cut difference in acceptability of dative cliticization depends on a very sloppy definition of the verbs allowing for this cliticization onto the causative

The ergative hypothesis for causative constructions in French was designed to account for the noncliticization of certain lexical datives onto the causative However, this hypothesis is at odds with some further restrictions on cliticized lexical datives The insertion of verbs like donner, promettre, conselller, interdire in the causative scheme NPI lut Vcaus Vinf $N P 2$ yields ambiguous sentences The dative $l u l$ on the causatıve can function as the indirect object of the infinitive or as its interpretive subject (Agent) The dative functioning as the interpretive subject of the infinitive actually is a nonlexical ${ }^{4}$ dative originating in the causative (Milner 1982)

Arnaud luı a falt/entendu donner/conseller/promettre des livres

'Arnaud made/heard him give/recommended/promise books (to someone)

'Arnaud made/heard books be given/recommend/promısed to him (by someone)'

When a complement introduced by par is inserted into these sentences, the dative can only be interpreted as the indirect object of the infinitive, since the par-complement absorbs the Agent role

Arnaud lu1 a fait/entendu donner/conseller/promettre des livres par Paul

'Arnaud made/heard books be given/recommended/promised to hım by Paul,

However, verbs like emprunter, demander, opposer do not generate ambiguous sentences when inserted in the abovementioned construction the dative $l u l$ can only function as the interpretive subject of the infinitive In causative constructions with these verbs, the dative $l u t$ is always of the nonlexical type 
(14) a. Charles lui a fait/vu emprunter/demander/soustraire cette somme.

'Charles made/saw him borrow/ask/withdraw that sum.'

b. Le directeur leur a entendu opposer cet argument.'

'The director heard them oppose that argument.'

c. Je lui ai vu préférer ce candidat.

'I saw him prefer that candidate.'

This absence of ambiguity suggests that the lexical dative clitic of verbs such as emprunter, demander, opposer cannot be attached to the causative. This hypothesis is confirmed by the insertion of par $N P$ which yields unacceptable sentences.
a. *Charles lui a fait/vu emprunter/demander/soustraire cette somme par cet escroc.
'Charles made/saw that sum be borrowed/asked/withdrawn from him by that scoundrel.'
b. * Le directeur leur a entendu opposer cet argument par son secrétaire.
'The director heard that argument be opposed to him by his secretary.'
c. *Je lui ai vu préférer ce candidat par le directeur.
'I saw that candidate be preferred to him by the director.'

The lexical dative of verbs such as demander, emprunter, opposer can only be lexically present at the right of the causative construction to function as the indirect object of the infinitive.

(16) a. Charles a fait/vu emprunter/demander/soustraire une somme considérable à cet homme par cet escroc.

'Charles made/saw a considerable sum be borrowed/asked/ withdrawn from that man by that scoundrel.'

b. Le directeur a entendu opposer cet argument au personnel par son secrétaire.

'The director heard that argument be opposed to the personnel by his secreta:y.'

c. J'ai vu préférer par le directeur ce candidat inconnu à son propre frère.

'I saw that candidate be preferred by the director to his own brother.'

These data show that restrictions on dative cliticization also apply to ditransitive verbs which clearly have nothing to do with the ergative-inergative 
distinction. It will be clear by now that inergative verbs only constitute a subset of the verbs that do not allow for their lexical dative to be cliticized onto the causative. If the ergative hypothesis were maintained, further restrictions would be necessary in order to deal with these observations. This hypothesis clearly fails to account for all restrictions on the cliticization of lexical datives in the causative construction.

\section{A THEMATIC RESTRICTION ON DATIVE CLITICIZATION}

These restrictions can be accounted for straightforwardly when the thematic relations linking the infinitival arguments are taken into consideration. The so-called 'ergative verbs' have a semantic characteristic in common: their indirect object is the Goal argument of the subject-Theme. A parallel observation can be made for infinitives such as donner, conseiller, promettre (cfr. (12)), where the direct object is a Theme and the indirect object a Goal argument. In the causative construction, the Theme arguments of both types of infinitive are redistributed around the causative construction as direct objects, and the indirect object Goal can be cliticized on the causative. Whenever the indirect object of the infinitive is not a Goal argument, pronominalization on the causative is impossible. First, it can be noted that the thematic function of the indirect object selected by verbs like emprunter, réclamer, demander, soustraire can be identified as a Source. For the 'inergative' verbs mentioned (mentir, nuire, obeir, résister etc.), this thematic function cannot be clearly defined. However, for our purpose it is sufficient to say that only indirect objects with a Goal function can be cliticized on the causative. The contrast noted in the following sentence can also be explained along these lines.

\footnotetext{
a. * Je lui fais téléphoner/avouer Mathilde. 'I (to him) make call/confess Mathilde.'

b. Je lui fais téléphoner/avouer cette histoire par Mathilde. 'I (to him) make call/confess this story by Mathilde.'
}

Unlike thematic functions of the Agent-Patient type, thematic functions of the Source-Goal type can be thought of as essentially relational. We can say that a Source/Goal function is only fully realized in its link with a Theme. The Theme-Source or the Theme-Goal relation can be conceived of as chain which bears the thematic function. An independent argument for this position can be found in the fact that the only argument of intransitive verbs can be Agent or Patient, but never Source or Goal. ${ }^{5}$ If this characterization of the Source/Goal relations is correct, the impossibility of (17a) and (3b) is due to the fact that the Goal function cannot be attributed to the indirect 
object. Since the Theme argument is left unexpressed, the thematic Goal chain does not obtain. Consequently, the indirect object clitic cannot be considered a Goal argument, and the sentence is unacceptable by virtue of the general restriction on cliticized Goal datives. On the contrary, (17b) is fully acceptable because the Theme argument is expressed.

Note however that the Goal restriction only applies to lexical datives. At first sight, certain nonlexical datives can be interpreted as Source arguments.

(18) Je lui ai fait/vu arracher/confisquer/rafler ce manteau par mon serviteur.

'I made/saw that coat be taken away from him by my servant.'

If the Goal restriction is only to be applied to lexical datives, we should be able to give a formal definition of both lexical and nonlexical datives. In Rooryck (1987b) it is shown that lexical and nonlexical datives can be distinguished by two formal tests. Unlike the lexical dative, this type of dative cannot appear in the passive construction, or in a construction with a clitic direct object and a lexicai indirect object. These properties can be explained if the nonlexical dative is viewed as an essentially clitic element that can marginally be lexicalized (see note 4). Moreover, the absence of nonlexical datives in passive constructions shows that this type of dative has no argument status and is co-selected by the direct object function.
a. * ? Je l'ai arraché/confisqué/raflé à Martin.
'I took it from Martin.'
b. * ?Ce manteau a été arraché/confisqué/raflé à Martin.
'That coat was taken from Martin.'

(20) a. Je l'ai demandé/emprunté à Martin.

'I asked/borrowed it from Martin.'

b. Ce manteau a été demandé à Martin.

'That coat was asked/borrowed from Martin.'

It can be observed that the thematic function of the nonlexical dative is not stable: in principle, a Benefactive/Malefactive reading obtains, depending on the interpretation of the sentence.

Je lui ai pris ce livre.

'I took that book for/from him.'

However, with certain types of NP (body parts, clothes) this thematic relation can denote a more precise inalienable possession. 

a. Je lui ai cassé le bras.
'I broke his arm.'
b. Je lui ai vu cette jupe.
'I saw that skirt on her.'

As we noted above, this nonlexical dative can also function as the interpretive subject (Agent) of the infinitive (Rooryck 1988). We would like to maintain that the Source interpretation is imposed on the thematic instability of the nonlexical dative which normally has a Benefactive/Malefactive interpretation.

The abovementioned restrictions on the cliticization of datives in the causative construction can be accounted for by the descriptive condition that only lexical datives with the thematic function of Goal can be pronominalized on the causative.

Although this restriction covers the cases hitherto mentioned, some exceptions can be found.
a. Mme. Lafontaine leur a entendu reprocher ces erreurs par l'in- stituteur.
'Mrs. Lafontaine heard these errors be reproached to them by the teacher.'
b. Je lui ai vu pardonner sa tentative de meurtre par le Pape. 'I saw his attempt to murder be forgiven to him by the Pope.'

The lexical dative of the verbs reprocher, pardonner cannot be analyzed as a Goal of the direct object Theme. Nevertheless, the sentences cited are fully acceptable and thus contradict the restriction on cliticized datives. Consequently, we will have to reformulate this descriptive condition if we want to account for these data. In order to achieve this goal, we want to reformulate the thematic relations of the Source/Goal type. For all verbs analyzed, the Theme-Goal relation can be viewed as a relation that obtains possibly (proposer, conseiller, promettre) or necessarily (arriver, parvenir/donner, téléphoner), or that is prevented (cacher, camoufler, interdire) at a time $t_{1}$ after the time of action $t_{0}$ of the verb itself. In Rooryck (1987a), the Theme-Goal relationship is analyzed as a relation of contact between an argument $Y$ and an argument $Z$ at a time $t_{1}$. Likewise, the Theme-Source relation can be described as a contact between an argument $Y$ and an argument $\mathrm{Z}$ at a time $\mathrm{t}_{-1}$ before the time of action $\mathrm{t}_{0}$ of the verb under analysis. A Theme-Goal relationship only makes sense when a contact between Theme and Goal is implied. Now, for judgment verbs such as reprocher, pardonner the semantic relation holding between the direct object and the indirect object can also be described in terms of contact. 
'I forgive/reproach Louis that error.'

From the point of view of the agentive subject, there is a relation of contact between these two arguments: Louis is responsible for the error. As argued in Rooryck (1987a), this relation is independent of the time of action $t_{0}$ of the verb. On the contrary, verbs of the type ressembler, nuire, obeir do not imply any contact between the lexical dative and the subject Theme. Verbs like demander, réclamer, emprunter however do imply a contact between the lexical dative and the direct object. Since this relation is between a Theme and a Source, it occurs at a time $t_{-1}$ before the time of action $t_{0}$ of the verb.

It could be objected that the notion of contact is used metaphorically in the case of reprocher, pardonner, while it is not for verbs implying a 'real' Theme-Goal contact relation. Why do pardonner and reprocher imply contact and not e.g. nuire? However, the presence or absence of a 'contact' relation can be tested by using paraphrases of these relations as relevant inferences. Thematic relations of the Agent-Patient type involve relations of power exerted by someone or something on someone or something. The notion of 'contact' does not imply this type of relation. Rather, it must be expressed as a relation of 'having/being' or 'being responsible for'. A relation of power cannot be expressed in these terms: a Patient undergoes the power of the Agent. The relation of contact can be paraphrased by the verbs avoir, être, recevoir (have, be, receive), a relation of power by subir (under$g o$ ). The verbs we have analyzed as implying a 'contact' relation construct sentences to which a 'contact' paraphrase can be adjoined, but not a 'power' paraphrase.

a. Je lui ai reproché/pardonné son imprudence, donc, de mon point de vue, il a été imprudent $/ *$ il a subi l'imprudence. 'I reproach/forgive him his carelessness, so, from my point of view, he has been careless $/ *$ underwent carelessness.

b. Ce message lui est parvenu/arrivé/échappé, donc il l'a eu/reçu/*subi.

'That message (to/from him) arrived/escaped, so he has had/*undervent it.'

c. Je lui ai donné/demandé ce livre, donc, de mon point de vue, il doit l'avoir/*le subir.

'I gave/asked him that book, so, from my point of view, he should have/*undergo it.'

Note that in all these cases the 'contact' paraphrase cannot be negated without obtaining a contradiction. This shows that the paraphrase can be 
viewed as a necessary implication of the preceding sentence. ${ }^{6}$ The verbs that do not allow for their dative to be cliticized on the causative do not imply 'contact' paraphrases.

a. *Elle lui ressemble/succède/ment, donc elle/il l'a eu/reçu/subi. 'She resembles him/follows him up/lies to him, so she/he has had/received/underwent her/him.'

b. Elle lui a obéi/résisté/cédé/survécu, donc elle a dû le subir/*l'avoir/*le recevoir.

'She obeyed/resisted/gave way/survived (to) him, so she has had to undergo $/{ }^{*}$ have $/{ }^{*}$ receive him.

The contrast between bénéficier (contact, Theme-Goal) and nuire (AgentPatient) is particularly revealing in this respect.

a. Ce comportement lui a bénéficié, donc il a dû en obtenir/*subir quelque chose.

'That behaviour benefited to him, so he got something out of it/*underwent it.'

b. Ce comportement lui a nui, donc il a dû en subir/*obtenir quelque chose.

'That behaviour harmed him, so he has had to undergo it/*did not get/got something out of it.'

The metaphorical use of the notion of contact is not only possible, it is even necessary in order to explain certain examples of dative cliticization on the causative.

a. Dieu leur a fait apparaître la Vierge.

'God made the Virgin appear to them.'

b. La Vierge est apparu aux enfants, donc ils l'ont aperçue/*subie. 'The Virgin appeared to the children, so they have seen/*underwent her.'

In addition to the 'psychological' (25a), 'physical' (25bc) or 'indirect' (27a) contact, the paraphrase of $(28 \mathrm{~b})$ indicates that some sort of 'eye-contact' is necessarily ${ }^{7}$ established between the referents of the arguments of apparaitre. For the verbs that do not allow for dative cliticization on the causative, no 'contact' paraphrase can be used as a necessary inference, although in some cases 'power' (Patient) paraphrases are possible (cfr. (26b)).

This rethinking of thematic relations of the Source/Goal type allows for a reformulation of the restriction on cliticized lexical datives in the causative construction. Only datives that can entertain a relation of contact with an 
expressed Theme argument at a moment $t_{1}$ after the time of action of the verb can be cliticized on the causative. Since the relation of contact between the direct and indirect object of judgment verbs like reprocher, pardonner is independent of the time $t_{0}$ of the verbal action, the restriction formulated also includes these verbs.

\section{CONCLUSION}

I have tried to show that the ergative hypothesis is unable to provide a correct account for the restrictions on the cliticization of lexical datives in the causative construction. In order to give a correct description of these restrictions, I have proposed a descriptive semantic condition stipulating that only lexical datives of a certain thematic type may cliticize on the causative. In this way, a single subcategorization scheme can be maintained for the causative 'restructuring' construction of type (4).

A last question that I want to raise concerns the theoretical relevance of this analysis. How can the approach presented here be integrated in an existing theoretical framework? Only the pronominal approach presented in Blanche-Benveniste (1984) seems to offer an adequate framework in which to account for these restrictions. Since this approach distinguishes syntactic functions on the basis of their possibility to enter certain constructions, the distinction they already draw between lexical datives of the P2 and the P3 type can be used to formally define the restriction noted on the cliticization of lexical datives on the causative. ${ }^{8}$ On the semantic side, our approach of thematic relations clearly fits in a cognitive semantics framework along the lines of Langacker (1987) for the (prototypical) notion of contact between arguments. In this way, purely structuralist and anti-structuralist currents in respectively syntactic and semantic research seem to converge.

Research Assistant of the National Fund for Scientific Research

Department of Lingustics

$K U$ Leuven

Blyde-Inkomststraat 21

B-3000 LEUVEN

Belgıum

NOTES

* I would like to thank Beatrice Lamiroy, Ludo Melıs, Karel Van den Eynde and two anonymous referees of the Journal of Semantics for constructive comments and extensive discussions on this subject, and Dirk Delabastita for improving my English I would like to express my gratitude to the National Fund for Scientific Research (Belgium) for its financial support. 
1 As pointed out by Tasmowskı (1985 232-239), Damourette and Pichon (1911-1940 par 1059-2057) distınguish two infinitival constructions for French causatives This analysis also shows up in Blanche Benvenıste et alı (1984 186-188) In the first construction, the comple ments of the infinitival construction can be cliticized on the infinitive (a) This construction is currently analyzed as a sentential complement contaning an infinitive with an overt subject In the framework of Chomsky $(1981,1986)$, this construction can be analyzed along the lines of ECM verbs (believe) in English For such an analysis in the barner-framework, see D'Hulst and Rooryck (forthcoming) In the second construction, nothing can appear between the main verb and the infinitive which merge into a complex verb by a restructuring operation (b) This operation is introduced as a Thematic-Index Rewriting rule by Rouveret and Vergnaud, a rule of Unıon (Fauconnier 1983), or 'Faire attraction' (Milner 1982) See Rooryck (1988) for a critı cısm of this type of analysis which was first advocated by Kayne (1977)

a Je le fars/entends/vors/lasse leur en donner

'I make/hear/see/have him give them of it'

b - Je leur en fars/entends/vors/laisse donner

'I make/hear/see/have give them of it'

- J'en fass/vors/entends/laisse donner par eux

'I make/hear/see/have gjve them of it by them'

- J'y fais/vols/entends/laisse partier/manger Theophraste

'I make/hear/see/have Theophraste leave/eat there'

2 This double subcategorization of the causative 'restructurng' construction clearly is in contradiction with the unified account of the causative 'restructuring' construction as a categorial 1diom (Rooryck 1988)

3 These verbs are goûter, nutre, repugner, rester, satısfaire, aller, conventr, adventr, appar tenir, deplaire, importer, manquer, peser, plaire, reussir, seoir Nutre is an interesting case, since the verb seems to be acceptable in the causative construction with an animate subject, and unacceptable with an inanimate subject This opposition is probably due to the strong correlation between agentivity and antmacy

J'al fait/vu nuire *cette situatıon/" ce directeur aux interêts du personnel

'I made/saw this situation/this director harm the interests of the personnel

4 For the distinction between lexical and nonlexical datives, and for the restricions on the lexicalisation of nonlexical datives, see Leclere (1976), Barnes (1980, 1985), Rooryck (1987b) See Rooryck (1988) for an analysis of the nonlexical ddtıve of causatıve constructions as the Agent of the infinitive

5 Moreover, for some ditransitive verbs, a correct thematic description requires that the rela tıon between Theme and Goal cannot obtan cacher, camoufler, interdire, refuser Now a negated Goal is simply nonsense, but a negation of the link Theme-Goal by the agentive subject seems to provide for an adequate thematic description of these verbs Note that they allow for the NPI lut Vcaus Vinf NP2 construction

Sa femme luı a fait cacher/interdire le vin par le medecin

'His wife made wine be stowed away/prohibited for him by the doctor'

6 However, some verbs imply negated contact relations, where a negated paraphrase is necessary (see note 5)

Je lur al interdit l'alcool, done de mon point de vue, ll ne pourra plus en avorr/*le subir 
'I prohıbited wine for him, so, from my point of view, he ts not allowed to have/*undergo it anymore

In this case, affirmation of the paraphrase yields a contradiction

7 This paraphrase cannot be negated without contradiction

8 Karel Van den Eynde, personal communication

\section{REFERENCES}

Bailard, Joelle 1981 A functional approach to subject inversion Studies in Language 5, 1, $1-29$

Barnes, Betsy 1980 The notion of 'Datıve' in linguistic theory and the grammar of French Lingvisticae Investigationes $4 \quad 245-292$

Barnes, Betsy 1985 A functional explanation of French nonlexical datives Studies in Language 9, 2 159-195

Blanche-Benvenıste, Clarre, J Deulofeu, J Stefanını and K Van den Eynde 1984 L'Approche Pronominale SELAF, Paris

Burzıo, Lu1g1 1986 Italian Syntax a Government-Binding Approach Reidel, Dordrecht

Chomsky, Noam 1981 Lectures on Government and Binding Foris, Dordrecht

Chomsky, Noam 1986 Barriers MIT Press, Cambridge Mass

Damourette, Jacques and E Pichon 1911-1940 Des Mots a la Pensee D'Artrey, Parls

D'Hulst, Yves and J Rooryck forthcoming An ECM analysıs of French perception and movement verbs

Fauconnier, Gilles 1983 Generalized unıon In L Tasmowskı and D W Wllems (eds), Problems in Syntax Communication and Cognition, 195-230

Goodall, Grant 1987 Parallel Stıuctures in Syntax Cambridge Unıversity Press, Cambridge

Gross, Maurice 1975 Methodes en Syntaxe Hermann, Paris

Kayne, Richard 1977 Syntaxe du Françals Le cycle Transformattonnel Le Seull, Parıs

Langacker, Ronald 1987 Foundations of Cognitive Grammar Vol I Stanford University Press, Stanford

Leclere, Chrıstian 1976 Datıfs syntaxıques et datıf ethıque In J Cl Chevalıer and M Gross (eds ) Methodes en Grammaire Françalse, K.lincksıeck, Parı, pp 73-96

Milner, Jean Claude 1982 Ordres et Rassons de Langue Le Seul, Parıs

Rooryck, Johan 1987a Les Verbes de Contrôle une Analyse de l'Interpretation du Sujet Non Exprtme des Constructions Infinttives er Françals Doctoral dissertation, $\mathrm{K} U$ Leuven

Rooryck, Johan 1987b Criteres formels pour le datıf non lexical en françaıs To appear in Studia Neophlologica

Rootyck, Johan 1988 French causatıver and the Dative problem Preprint nr 115, Department of Linguistics, $\mathrm{K}$ U Leuven

Rouveret, Alam and J -R Vergnaud 1980 Specifyng reference to the subject French causatives and conditions on represeatations Linguistic Inquiry $11 \quad 97-202$

Ruwet, Nicolas 1988 Les verber meteorologiques et l'hypothese inaccusative To appear in Claure Blanche-Benvenıste, Andre Chervel, and Maurice Gross (eds), Melanges a la Memorre de Jean Stefanin

Tasmowskı, Lilıane $19842 *$ 'Iu falre telephoner quelqu'un d'autre' une strategie Lingvistlcae Investigationes 8, 2, 403-427

Tasmowskı, Lilıane 1985 Faıre infinitıf In L Melıs (ed), Les Constructıons de la Phrase Françatse Communicatıon and Cognitıon, 223-365 